\title{
The Investment In Management Information Systems And Its Effect On The Efficiency In Public Organizations When Putting Into Practice The Alignment Function Of Information Technologies Governance
}

Eduardo Javier Santillán Muñiz, Universidad Anáhuac México Sur, México

\begin{abstract}
In a globalized world, companies creating computer software (software) try to standardize problem solving for all kinds of organizations, whether public or private. While there are powerful tools for the analysis, design and implementation of systems management, some public enterprises acquire systems instead of creating them, with a costly and unproductive maintenance. The socalled Balanced Scorecard is used in this process, which measures systems management productivity through the Information Technology Infrastructure Library, making efficient investments in Information and Communication Technologies as a result. This paper is an exploratory research, which will review the degree of control over the systems that exists in public organizations in Mexico.
\end{abstract}

Keywords: information technologies and communications, balanced scoreboard, strategic management, public enterprises

\section{INTRODUCTION}

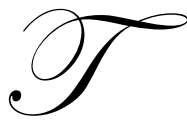

he Mexican Government's National Development Plan, in reference to the strategic Electric Sector 15.10, states: "To strengthen the enterprises of the sector, adopting international industry standards and operating practices, enhancing processes by the implementation of high tech quality systems, and promoting a more efficient use of the budgeted cost of expenses and investments" (República, 2007).

It is necessary to promote an efficient use of investments, because public enterprises invest a lot of money in Management Information Systems (MIS). However, how can we know if the systems introduced into the market by software companies are efficient when used in this kind of organizations?

It is a known fact that important and costly investment resources in Information Technologies and Communications (ITC) are wasted and badly designed, with functions not needed by public enterprises.

The investment in MIS is applied to internal processes of organizational control, which measures and reports the efficiency and behavior productivity within the organization. However, the efficiency of information systems is not measured as is, and accordingly, it is not possible to define in a correct manner the requirements of ITC within each public enterprise.

The answer is putting into practice the alignment function of Information Technologies Governance (ITG) and the Balanced Scorecard (BSC) to measure the impact on the operational efficiency in public enterprises.

Moreover, it is necessary to identify the parameters for this kind of enterprises using the Information Technology Infrastructure Library (ITIL). 
When the variables obtained are visualized from the integration model, the necessary information is given for an evaluation of the investment in management information systems and its effect on the efficiency of the public organizations using the alignment function of Information Technologies Governance (ITG).

\section{PUBLIC ENTERPRISE MANAGEMENT}

Politicians, who administer the public enterprises, are unable to define in a correct manner the mission and vision of public organizations (Matthías, 2007). Generally speaking, the organizations tend to create a vision and a mission out of reality.

Accordingly, it is very difficult to implement this reality within the organization (Robbins, 2004), and consequently, the work to be done does not agree with what is expected in the future.

When the employees do not have a clear idea where the organization is headed to, work is easily lost between so many projects, which at the end are not finished and accordingly a work is done in vain.

This work costs the organization time, money and an important distraction of what really should have been done. As a result, if the mission is not declared correctly, the organization does not have an idea of where to go (David, 2003), and thus loses its path.

In addition, this lost path is lost work, and not just by employees, supervisors and managers, but also by senior executives or politicians. At the same time, when a project could result in a positive outcome for the organization, the employees may not see this innovation or enhancement offered, and the project might end without having been put into practice.

Therefore, how can efficient results in this kind of enterprises be asked for, if there is no planned path to meet the objectives that the organization has outlined. The outlined path for public enterprises in many occasions responds to a political plan, which contains objectives and strategies to win elections and not to offer an efficient service to their clients.

In conclusion, the public administration should know its business (Drucker, 1999), and must evaluate the results of its performance with clear and transparent information, and thus avoid productive inefficiencies (Rosales, 2004).

The continued enhancement (Drucker, 1996) will result in the possibility that the processes tend to be more suitable, efficient and could end up synthesized in Management Information Systems (MIS), fast and efficient.

\section{MANAGEMENT INFORMATION SYSTEMS}

The enterprises of today, being public or private, need to inform and to be informed adequately. The MIS are helpful tools for administrators to get to know their companies.

These systems function in many enterprise processes, giving information about accounting, sales, human resources and other processes (Laudon, et al, 2004). They function with a collection of files that show information about the services that are given to clients, employee productivity and the company's financial position among many other kinds of information.

This collection of files is organized in fast working and reliable databases, and more important, with results up-to-date (Date, 2001). Those systems that work with non-repetitive data give true information.

Furthermore, modern programming techniques, like analysis and design of object-oriented systems (Martin, et al, 1992), create variables with attributes and by means of certain methods their own functionality. These objects or variables are found in the data base listings to be consulted. 
Moreover, with the Internet, that is based on the scheme client-server (McLeod, 2000), simple computers can be employed for consulting information using Browsers - Microsoft Explorer, Mozilla Firefox and others - that utilize methods for consulting and modifying databases to obtain reports that the organization needs for its administration.

The new business models (Barber, 2007) are based on the usage of the Internet, Extranet and Intranet, using friendly interfaces between the computers and the users.

The Intranet helps the public enterprises to inform their employees (Ochoa, et al, 2004) about the Mission, Vision, policies, procedures, and other functions that intend to improve the efficiency of the work methods used by the workers belonging to these organizations.

The public enterprises can and should use this communication model, which surely will improve the internal processes. On the other hand, systems development should be divided into well-defined phases and processes (Stair et al, 2000) before the creation of computer programs. If the public enterprises establish groups of specialists to create these programs, the use of ITC will be more efficient.

Accordingly, the systems maintenance will be more efficient, because a group of specialists is prepared to care of any emergencies.

Furthermore, the subsistence of the systems is linked to the user operation; therefore, it is necessary to have a Complaints System to be able to know if the procedures, the functionality and the availability are efficient.

The complaints will guide the service providers to become more efficient towards the clients (Barlon et al, 1996), so why not create an enterprise process user Complaints System of how to improve the procedures in which the users are involved?

The Information Technology Infrastructure Library (ITIL) is developed as a complaints system, where the systems in operation in the organization are monitored and information about their behavior is captured.

\section{INFORMATION TECHNOLOGY INFRASTRUCTURE LIBRARY (ITIL)}

ITIL was created when it was admitted that the organizations depend more and more on computing to meet their corporate objectives.

As a result, this dependency has resulted in growing needs for qualified systems services that correspond to the objectives of each particular business, which will satisfy the clients' requirements and expectations.

The ITC application contributes to achieve the corporate objectives only if the system can be used by the users, and, in case of failure or necessary modifications, supported by maintenance and operational processes.

Beginning year 2000 a revision of the ITIL was undertaken. The central books have been grouped into two, covering the Service Support and Service Planning areas (OSIARIS, 2007).

a) Service Support

The Service Support areas are responsible for every operational aspect that guarantees the continuity, availability and quality of services available to the user. To achieve these aspects it is required to manage correctly the following systems:

- The Incidents Management System: Its objective is to resolve any incident that causes an interruption of the service, as fast and efficient as possible.

- $\quad$ The Problem Management System: In charge of investigating the underlying causes to all alterations, real or potential, of the ITC service, determining possible solutions and proposing necessary petitions of change to reestablish the service quality. 
- $\quad$ The Infrastructure Management System: Evaluates and plans the enhancement process to guarantee, when it is implemented, that it is done in the most efficient manner, following the established procedures to assure in every moment the ITC service quality and continuity.

- The Configurations Management System: Keeps control of every configuration element identified in the ITC infrastructure, with an adequate level of detail, managing the information through the Data Base Configuration.

b) Service Provision

The Service Provision takes care of services offered as a whole, in particular of the service level availability, continuity, and financial feasibility, the necessary capacity of the ITC infrastructure and the required levels of security.

- $\quad$ The Availability Management properly optimizes and monitors the ITC services functions so they work with no interruptions and in a reliable manner.

- $\quad$ The Financial Management evaluates and controls the costs associated with the ITC services in a manner that a quality service is given to the clients with an efficient use of the necessary ITC resources.

- $\quad$ The Capacity Management is in charge of that all ITC services are backed up by a process capacity and with sufficient and correctly dimensioned data storage.

- $\quad$ The Service Continuity Management worries about preparing for an unforeseen and severe ITC services interruption, due to a natural disaster or other causes of force majeure, which could end in catastrophic consequences for the business.

- $\quad$ The Security Management should take into consideration that the information is correct, its availability to the business and just by those who have the required authorization.

The information that ITIL recollects should be the input to BSC and ITG.

\section{INFORMATION TECHNOLOGY GOVERNANCE}

The ITG, being a responsibility of the Board of Directors or the organization's senior executive officers, constitutes an essential part of the enterprises' governance as a whole, and unite the organizational structure and direction to assure that the information technologies support and assist in the development of the strategic objectives defined (AEMES, 2006). The ITG objectives are:

- $\quad$ Align strategically with the objectives of the business

- Optimize its management by means of a constant monitoring and the continuous improvement of the processes

- $\quad$ Improve the organizational capacity to manage opportunities and maximize benefits

- Use in a responsible way the resources in the fulfilling of the objectives

- $\quad$ Manage in a proper manner the associated risks

- $\quad$ Publish within the organization the obtained benefits due to the investments put in effect.

Requirements for a well-done ITG (Carrillo, 2006)

1) The existence of an adequate reference frame:

a. Structure: Who takes the decisions? What organizational structures are to be created, and who are going to participate in them and what responsibilities will they get?

b. Processes: How will the decisions be taken in reference to investing in ITC? Which are the decisionmaking processes for proposing investments, reviewing them, authorizing them, and defining investment priorities?

c. Communication: How will the results of these processes be followed-up, measured and communicated? What mechanisms will be utilized for communicating the decisions of investment to the Board of Directors, Senior Executive Management, and Senior Sales Management, IT Senior Management, employees and shareholders? 
2) Have in mind the principles of how the ITC function within the organization.

3) Do not confuse strategic actions with tactics and operative actions during the ITG implementation.

4) The responsibility of initiating the decision making of the governance process lies on the Board of Directors/Senior Executive Management.

5) The Chief Information Officer (CIO) must be the promoter of the idea and co responsible for the implementation of the governance processes.

6) The key factor to success is to decide who takes the decisions and based upon what factors

7) It is a continuous learning process and its cycle is of continuous enhancements.

The ITG, when adequately implemented, is a discipline of Corporative Governance (Zamora, 2007). The Board of Directors must be the entity that "directs" the operation of the Information Technology Management. The ITG must be established and managed considering the three dimensions of Corporate Governance: Fulfillment, Performance, and Responsibility in respect to their obligations under the law.

The strategic planning is a managerial process that consists of developing and maintaining a strategic adjustment between the objectives and resources of the enterprise and its opportunities according to the changing market. Accordingly, the elements or measurement indicators for the BSC must be defined.

\section{BALANCED SCORECARD (BSC)}

The BSC transforms the mission and strategy into objectives and indicators organized in four different perspectives: Finance, Clients, Internal Processes, and Formation and Growth (Kaplan et al, 1996).

These four perspectives form a framework, a structure and a language to communicate the mission and the strategy, using the measurements to inform the employees about the reasons for the actual success and the upcoming future.

The BSC is more than a system of tactical and operational measurement. The innovators are using it as a system of strategic management, to manage their strategy in the long term and to carry out processes of decisive management:

- $\quad$ Explain And Translate Or Transform The Strategic Vision

- $\quad$ Communicate And Subdue The Objectives And Strategic Indicators

- $\quad$ Plan, Establish Objectives And Align The Strategic Initiatives

- $\quad$ Augment The feedback and strategic formation

The BSC retains the financial perspective, because the financial indicators are valuable for resuming the economic consequences, easily measured for actions already put into practice. The results of the financial measurements indicate if an enterprise's strategy and execution contribute to a minimum acceptable improvement. From the client's perspective, the directives identify the client and market segments, where the enterprise is competing and the performance measurements in these selected segments. The fundamental indicators include the satisfaction, retention, acquisition of new clients, the client's profitability and the market quota in the selected segments.

From the internal process perspective, the executives identify the critical processes where the organization must be excellent. The measurements of the internal processes are centered in the processes that will have the major impact on the client's satisfaction and on the achievement of the organization's financial objectives.

Perspectives of formation and growth identify the infrastructure that the enterprise must construct to create a better performance and growth in the long term. The client's perspectives of the internal process identify the most critical factors for the present and future success.

It is improbable that public enterprises would be capable of catching up with their objectives in the long term, when clients use the present technologies and internal process capacities, and more, the intense global 
competence demands that the enterprises improve continuously their capacities to deliver value to their clients and shareholders.

The formation and growth of an organization are originated in three principal sources: the persons, the systems and the organization's procedures.

The information systems' capacities can be measured through the real-time availability of liable and important client information and of the internal processes, which are facilitated to the employees, primary found in the decision-making and execution.

\section{DISCUSSION}

It is well known that the public enterprises invert large amounts of money in the ITC, but what is not known is how to correctly measure the ITC efficiency and be able to affirm that the investments in the ITC are correctly evaluated.

Some of the most important questions are of two kinds: for the administrators and for the users of the IT services. For the first ones:

- $\quad$ Are the processes understood in reference to systems and technologies areas?

- $\quad$ Does the system comply with the organization's internal control?

- How is the ITC strategy established in the public enterprises?

- Is the present situation of the IT area known?

- $\quad$ Does an excellent cost-benefit relation exist?

- Does security exist for the personal, the data, the hardware, the software and the installations?

- $\quad$ How to decide which projects and initiatives should be put into effect?

- Has the public enterprise some objective form of evaluating the ITC performance?

For the second ones:

- $\quad$ Are major integrity, confidentiality, liability and availability of the information assured?

- Does the IT function facilitate the goals and objectives of the organization?

- Is the user satisfaction of the IT systems incrementing?

- $\quad$ Does training and education exist in reference to the Information Systems (IS)?

Although ITIL looks for an answer to these and other questions, the system looks for ideas to make efficient the systems of the organization through the capture of statistical data of system failures and data referring to the clients' satisfaction.

In public enterprises it is easy to change from a system to another, knowing that the latter is better equipped, i.e. has a quality that is superior than the first one and because of this fact it is purchased and installed..

The problem lies in that a large cost in systems should have a reasonable answer in the productivity of persons, processes, or even better in the service quality to the client, but it is not so.

If the cost of ITC really were evaluated, the administrators could augment a $100 \%$ the use of systems by the implementation of these technologies.

The variables to be measured in the BSC should be obtained from its most reliable origin, i.e. the use of the systems; the complaints on a regular basis are the most reliable source that has been used, where the majority of the failures can be identified.

In organizations where a complaints system does not exist, apparently, nothing fails and even if these systems exist, in many occasions the same persons avoid that these failures are made public. The complaints are very important as knowledge of how the services of any enterprise are given. 
Even if ITIL was not a complaints system, it should be used as such, because procedures are available with better administration practices of IT resources. ITIL indicates which will be the necessary variables of how to obtain the statistics of the system use. At the same time, the variables should be handled from a control board, where the BSC helps with the correct strategy, aligning the variables to the goals or established objectives by the enterprise management. When high qualifications are obtained, these indicate that the use of the systems is of help to the personal, the administrators, and executive management, to do their work correctly.

Where satisfied clients can be found, high qualifications of the services that the enterprise is offering will exist, and if it is so, the systems really help to obtain client satisfaction. If the latter were the case, the investments already put into ITC have been correctly placed. In case the contrary occurs, the enterprise's strategic planning, the systems and the investments in ITC must be evaluated.

The hypothesis of this work intends making understandable how investments in ITC should be done.

"If an adequate alignment of INFORMATION TECHNOLOGY GOVERNANCE in public enterprises is done, by putting into practice the Balanced Scorecard by means of the identification of appropriate parameters; then, there will be an efficient use of investments in management information systems, to make more profitable the operation of this kind of enterprises".

\section{CONCLUSION}

The result of this investigation shows how to demonstrate the efficiency or inefficiency of the information systems. Also, gives advice to higher management to take into account MIS that have been used in public enterprises, used with success or not, and who have used them, forming a database relative to this information.

At the same time, takes into consideration technical decisions, as well as administrative, and first of all the financial ones to achieve an efficient selection in the development, leasing or purchase of ITC.

The expected results of the investigation in the public administration are the following:

- Development of a methodology, to make more useful the management information systems

- $\quad$ Establish a model to align the processes of IT in the public sector

- $\quad$ Identify the appropriate parameters of alignment for public enterprises

- $\quad$ Contribute with elements to enrich the theory of public enterprises administration

Accordingly, the following phases should be taken into account:

- $\quad$ Carry out an exploratory investigation to obtain information about the existing systems.

- Carry out interviews and questionnaires with the system users to verify their satisfaction or dissatisfaction towards the service that the system area offers.

- $\quad$ Describe system costs in the public enterprises.

- $\quad$ Document the existing use of ITIL and ITG in the public enterprise.

By obtaining the above information, the mechanisms are created for implementing a model of ITIL into an ITG system, and the BSC generated with the appropriate measurement parameters for the public enterprises.

\section{AUTHOR INFORMATION}

Eduardo Javier Santillán Muñiz, Comisión Federal de Electricidad (CFE), México City, México. CFE generates, transmits, distributes and commercializes electricity to customers in México. I've worked at CFE since 1976 developing information systems for all the company, both (engineering and administrative). I studied Business Administration at Universidad Anáhuac México Sur and a got a masters degree in Engineering Business Systems. I'm studying a PhD in administration applied Research at Universidad Anáhuac México Sur. 


\section{REFERENCES}

1. AEMES, V. C. (2006). Estrategias para la Mejora en el Gobierno de las Tecnologías de la Información. Madrid.

2. Barber Kuri, C. (2007). Modelos de negocios del siglo XXI; esencia y tendencias. Año XXXIII. No. 1.

3. Barlon, J., \& Moller, C. (1996). Una queja es un favor. Colombia: Norma.

4. Carrillo Verdún, J. D. (2006). VII Conferencia AEMES 2006 ¿Qué es el Gobierno de TI? Modelos de Madurez, Indicadores y Métricas. Madrid.

5. Date, C. J. (2001). Introducción a los Suistemas de Base de Datos. México: Prentice All.

6. David, F. R. (2003). Conceptos de Administración Estratégica. México: Prentice Hall.

7. $\quad$ Drucker, P. (1999). La gerencia de Empresas. Argentina: Sudamericana.

8. $\quad$ Drucker, P. (1996). Su Visión sobre la Administración. Colombia: Norma.

9. Huerta Moreno, G. (2007). Gestión y estrategia. Recuperado el 13 de 11 de 2007, de http://www.azc.uam.mx/publicaciones/gestion/num4/doc5.html

10. Kaplan, R. S., \& Norton, D. P. (2007). Las Medidas del éxito. Edición especial.

11. Kaplan, R. S., \& Norton, D. P. (1996). The Balanced Scorecard. Boston Massachusetts: Harvard Business School Press.

12. Laudon, K. C., \& Laudon, J. P. (2004). Sistemas de Información Gerencial. México: Pearson Prentice Hall.

13. Martin, J., \& Odell, J. (1992). Análisis y diseño orientado a objetos. México: Prentice All.

14. Matthías, S. (2007). Planeación Estratégica en Empresas Públicas. México: trillas.

15. McLeod, R. (2000). Sistemas de información gerencial. México: Prentice All.

16. MEADOWS, R. (2007). Las nuevas herramientas de IT Governance ayudan al consejo de administración, gestión y auditores. Obtenido de ISACA:

http://www.isaca.org/Template.cfm?Section=Home\&CONTENTID=10301\&TEMPLATE=/ContentManag ement/ContentDisplay.cfm

17. Ochoa, J., \& Sotillos, L. (2004). 102 Claves de Tecnologías de Información para directivos. España: Prentice Hall.

18. Olve, N.-G., Roy, J., \& Wetter, M. (2000). Implantando y Gestionando El Cuadro de Mando Integral. Barcelona: Ediciones Gestión 2000.

19. OSIARIS. (2007). ITIL-Gestión de Servicios TI. Recuperado el 11 de 11 de 2007, de http://itil.osiatis.es/Curso_ITIL/index.php

20. R., F. A. Cobit 4.0 Nuevas características. Information Systems Audit and Control.

21. República, S. I. (13 de Noviembre de 2007). Presidencia de la Republica México. Recuperado el 13 de Noviembre de 2007, de http://pnd.calderon.presidencia.gob.mx/index.php?page=energia-electricidad-ehidrocarburos

22. Robbins, S. (2004). Comportamiento Organizacional. México: Prentice Hall.

23. Rodríguez Valencia, J. (2000). Introducción a la Administración con Enfoque de Sistemas. México: ECAFSA.

24. Rosales Nuñez, J. (2004). Gerencia Pública Administración Pública Contemporanea. México: Gernika.

25. Stair, R. M., \& Reynolds, G. W. (2000). Principios de sietmas de información. México: Thomson.

26. Zamora Sotelo, ,. C. (2007). Importancia del Gobierno de TI. ISACA. 